\title{
PIRANTI KOHESI GRAMATIKAL DAN LEKSIKAL PADA WACANA RUBRIK "SELEBRITAS" DALAM MAJALAH FEMINA SEBAGAI BAHAN AJAR MENULIS TEKS NARASI
}

\author{
Nila Prima Septianingrum dan Atiqa Sabardila \\ Pendidikan Bahasa Indonesia \\ Fakultas Keguruan dan Ilmu Pendidikan \\ Universitas Muhammadiyah Surakarta \\ nila_prima@yahoo.com \\ as193@ums.ac.id
}

\begin{abstract}
ABSTRAK
Tujuan penelitian ini adalah (1) memaparkan penggunaan piranti kohesi gramatikal dalam rubrik "Selebritas" di majalah Femina; (2) memaparkan penggunaan piranti kohesi leksikal dalam rubrik "Selebritas" di majalah Femina; dan (3) mengimplementasikan penggunaan piranti kohesi gramatikal dan leksikal dalam rubrik "Selebritas" di majalah Femina sebagai salah satu bahan ajar menulis teks narasi. Adapun hasil penelitian ini adalah (1) piranti kohesi gramatikal yang dianalisis dalam penelitian ini terdiri atas 10 referensi, 6 konjungsi, 3 substitusi, dan 3 elipsis. Piranti kohesi referensi dibagi menjadi 7 referensi persona, 2 referensi demonstratif, dan 1 referensi komparatif. Referensi persona dibagi menjadi 1 pronomina orang pertama tunggal, 1 pronomina orang pertama jamak, 4 pronomina orang ketiga tunggal, dan 1 pronomina orang ketiga jamak; (2) piranti kohesi leksikal yang dianalisis dalam penelitian ini terdiri atas 7 ekuivalensi, 2 hiponimi, 2 antonimi, 2 repetisi, 1 sinonimi, dan 1 kolokasi; dan (3) hasil penelitian ini digunakan sebagai bahan ajar di Sekolah Menengah Pertama (SMP) kelas VII sesuai dengan Kurikulum 2013. Bahan ajar ini dapat diterapkan pada Kompetensi Inti 4 dan Kompetensi Dasar 4.5.1 yakni siswa diminta untuk menyusun teks narasi.
\end{abstract}

Kata kunci: piranti kohesi gramatikal, piranti kohesi leksikal, bahan ajar, teks narasi.

\section{ABSTRACT}

The purpose of this study are (1) describes the use of grammatical cohesion devices in the rubric "Selebritas" in the Feminamagazine; (2) describes the use of lexical cohesion devices in the rubric "Selebritas" in the Femina magazine; and (3) implement the use of grammatical and lexical cohesion devices in rubric "Selebritas" in Femina magazine as one of the teaching material to write narrative texts. The results of this study were (1) grammatical cohesion devices analyzed in this study consisted of 10 reference, 6 conjunction, 3 substitution, and 3 ellipsis. Counterfeit reference cohesion divided into 7 reference persona, 2 demonstrative reference and 1 comparative reference. Reference persona is divided into 1 pronoun first person singular, 1 pronoun first personplural, 4 pronouns third person singular, and 1 pronouns third person plural; (2) lexical cohesion devices analyzed in this study consisted of 7 equivalence, 2 hyponymy, 2antonym, 2 repetition, 1 synonymy and 1 collocation; and (3) the results of this research are used as teaching material in high school students of class VII in accordance with Curriculum 2013. These teaching materials can be applied to core competencies 4 and basic competence 4.5.1 which 
students were asked to compile a narrative text.

Keywords: grammatical cohesion devices, lexical cohesion devices, teaching materials, narrative texts.

\section{PENDAHULUAN}

Salah satu kompetensi dasar yang harus dicapai oleh siswa adalah menyajikan kejadian, urutan peristiwa, dan pesan dalam teks narasi secara lisan dan tulis. Kompetensi dasar tersebut terdapat pada Kurikulum 2013 dan perlu dituntaskan pada jenjang SMP kelas VII. Wacana narasi merupakan wacana yang paling mudah dan paling disukai oleh siswa karena wacana tersebut bersifat menceritakan. Siswa cenderung lebih suka membaca cerita, apalagi membaca cerita yang berkaitan dengan kehidupan sehari-harinya, misalnya ialah cerita mengenai tokoh idolanya.

Masih ada beberapa siswa yang karangan narasinya belum sempurna. Hal tersebut dapat dilihat dalam penelitian yang dilakukan oleh Ghufron. Ghufron (2012) meneliti "Peranti Kohesi dalam Wacana Tulis Siswa: Perkembangan dan Kesalahannya". Ghufron masih menemukan beberapa kesalahan yang terdapat pada karangan narasi yang disusun oleh siswa. Kesalahan yang ditemukan berkaitan dengan penggunaan piranti kohesi, yakni yang penggunaan konjungsi, elipsis, substitusi, referensi, dan repetisi. Jadi, perlu adanya bahan ajar yang digunakan untuk memperdalam lagi pengetahuan siswa yang berkaitan dengan piranti kohesi. Widodo dan Jasmadi (dalam Lestari, 2013:1) mengemukakan bahwa bahan ajar adalah seperangkat sarana atau alat pembelajaran yang berisikan materi pembelajaran, metode, batasan-batasan, dan cara mengevaluasi yang didesain secara sistematis dan menarik dalam rangka mencapai tujuan yang diharapkan, yaitu mencapai kompetensi atau subkompetensi dengan segala kompleksitasnya.

Salah satu wacana yang dimuat di majalah Femina adalah rubrik "Selebritas". Rubrik merupakan salah satu bagian yang selalu mengisi media cetak, baik berupa majalah, surat kabar, harian, dan lainnya. Dalam KBBI (2014:1186) rubrik diartikan sebagai kepala (ruangan tetap) dalam surat kabar, majalah, dan sebagainya. Rubrik "Selebritas" di majalah Femina merupakan rubrik yang berisi berita seputar kehidupan selebritas, baik selebritas nasional maupun internasional. Berita yang dimuat tidak melulu soal desas-desus kehidupan pribadi para selebritas, tetapi sering juga menampilkan prestasi atau cita-cita yang diraih oleh selebritas tersebut. Sosok selebritas sendiri memiliki tempat yang cukup dekat dengan para pembaca, terutama para remaja yang mengidolakan seorang selebritas. Oleh karena itu, rubrik "Selebritas" dalam Majalah Femina cukup baik digunakan sebagai salah satu media untuk mempelajari teks narasi di sekolah.

Piranti kohesi gramatikal merupakan piranti atau penanda kohesi yang melibatkan penggunaan unsur-unsur kaidah bahasa (Rani, 2006:97). digunakan untuk menghubungkan ide antarkalimat cukup terbatas ragamnya. Adapun menurut Mulyana (2005:27) unsur kohesi gramatikal terdiri dari reference (referensi), substitution (substitusi), ellipsis (elipsis), dan conjunction (konjungsi). Menurut Mulyana (2005:29) kohesi leksikal atau perpaduan leksikal adalah hubungan leksikal antara bagian-bagian wacana untuk mendapatkan keserasian struktur secara kohesif. Unsur kohesi leksikal terdiri dari sinonim (persamaan), antonim (lawan kata), hiponim (hubungan bagian atau isi), repetisi (pengulangan), kolokasi (sanding kata), dan ekuivalensi. Chaer (2012:272) menjelaskan bahwa wacana narasi bersifat menceritakan suatu topik atau hal. Dalam narasi terdapat unsur-unsur cerita yang penting, misalnya unsur waktu, pelaku, dan peristiwa.

Penelitian ini memiliki relevansi dengan beberapa penelitian terdahulu. Penelitian Prasetia (2013) berjudul "Penggunaan Piranti Kohesi dalam Karangan Narasi oleh Siswa Kelas VII 
SMP Negeri 1 Blahbatuh". Hasil penelitian ini menunjukkan bahwa piranti kohesi yang digunakan, antara lain piranti kohesi konjungsi 49\%, referensi 47,5\%, elipsis 1,8\%, repetisi 0,9\%, dan hiponimi 0,9\%. Adapun tingkat kekohesifan karangan narasi siswa kelas VII SMP Negeri 1 Blahbatuh tergolong rendah.

Rassouli (2013) meneliti "The Effects of Explicit Instruction of Grammatical Cohesive Devices on Intermediate Iranian Learner's Writing". Hasil penelitian ini yakni penggunaan perangkat kohesi dapat membantu peserta didik mengembangkan tulisan-tulisan yang lebih kohesi, tetapi kualitas tulisan para peserta didik belum meningkatkan sesuai dengan instruksi yang diberikan.

Chao (2014) melakukan penelitian dengan judul "Lexical Cohesion of Sino-British College Student's EAP Writing". Hasil penelitian ini menemukan bahwa penutur asli dan peserta didik EFL Cina cenderung menggunakan pengulangan kurang sederhana dan kohesi lebih rumit seiring membaiknya kemampuan berbahasa Inggris. Adapun frekuensi rata-rata kohesi leksikal yang digunakan oleh peserta didik EFL Cina kurang baik jika dibandingkan dengan penutur asli.

Nabifar (2015) melakukan penelitian dengan judul "A Constrative Study of Lexical Cohesion Used in Sport Texts in Washington and Tehran Times Newspapers Written by English Native and Iranian Authors". Hasil penelitian menunjukkan bahwa ada perbedaan yang signifikan secara statistik dalam penggunaan hubungan leksikal dalam teks koran olah raga. Selain itu, penelitian ini mengungkapkan bahwa ikatan leksikal koran Washington lebih rapat dari koran Tehran. Selain itu, penelitian ini juga memiliki beberapa implikasi bagi instruktur bahasa, mahasiswa, dan penulis Iran.

Olajoke (2015) meneliti “A Lexical Analysis of an Inaugural Speech of the Speaker of Benue State House of Assembly in Nigeria". Adapun hasil penelitian ini diketahui bahwa legislator menggunakan perangkat kohesi leksikal seperti pengulangan, sinonim, antonim, kolokasi, superordinasi untuk mencapai tujuan tertentu seperti interkonektivitas, keterusterangan, penekanan, apresiasi dan daya tarik dalam proses negosiasi makna dalam penggunaan bahasa.

Zarepour (2016) melakukan penelitian dengan judul "Cohesion Analysis of Iranian Advanced EFL Learner's Writing". Hasil penelitian ini adalah perangkat kohesi yang paling sering ditemukan adalah referensi kohesi diikuti oleh hubungannya, kohesi leksikal, elipsis, dan substitusi. Kesalahan kohesi yang paling sering dilakukan oleh peserta didik juga terkait dengan referensi kohesi, kohesi leksikal, elipsis, dan substitusi masing-masing.

\section{METODE}

Penelitian ini merupakan penelitian kualitatif. Data penelitian ini berupa kalimat yang mengandung piranti kohesi gramatikal dan leksikal. Sumber data penelitian ini berupa rubrik "Selebritas" yang terdapat pada majalah Femina edisi November 2015. Teknik pengumpulan data yang digunakan dalam penelitian ini adalah teknik pustaka dan teknik simak catat. Teknik keabsahan data yang digunakan oleh peneliti dalam penelitian ini adalah triangulasi dokumen atau data. Deviliana (dalam Rohmadi dan Nasucha, 2015:143) mengatakan bahwa triangulasi dokumen digunakan untuk menguji kebenaran data yang diperoleh dari dokumen satu dengan dokumen lain.

Data dalam penelitian ini dianalisis dengan metode padan, metode agih, dan teknik baca markah. Metode padan yang digunakan yaitu metode padan referensial. Teknik dasar dari metode padan yang digunakan adalah teknik ilah unsur penentu (PUP), yakni daya pilah referensial. Adapun teknik dasar yang digunakan dalam metode padan pada penelitian ini yaitu teknik hubung banding menyamakan (HBS). 
Teknik dasar dari metode agih yang digunakan adalah teknik bagi unsur langsung (BUL). Menurut Sudaryanto (1993:31) teknik BUL yaitu cara yang digunakan pada awal kerja analisis ialah membagi satuan lingual datanya menjadi beberapa bagian atau unsur, dan unsur-unsur yang bersangkutan dipandang sebagai bagian yang langsung membentuk satuan lingual yang dimaksud.

Teknik analisis data yang digunakan sebagai teknik lanjutan dari teknik BUL adalah teknik sisip. Tujuan penelitian pertama, yakni memaparkan penggunaan piranti kohesi gramatikal dalam rubrik "Selebritas" di majalah Femina dicapai dengan menggunakan teknik daya pilah referensial, teknik sisip, dan teknik baca markah. Adapun tujuan penelitian kedua, yakni memaparkan penggunaan piranti kohesi leksikal dalam rubrik "Selebritas" di majalah Femina dicapai dengan teknik daya pilah referensial dan baca markah.

\section{HASIL DAN PEMBAHASAN}

Data yang dikumpulkan pada penelitian ini sebanyak 37 data. Data tersebut diklasifikasikan menjadi dua, yakni piranti kohesi gramatikal dan piranti kohesi leksikal. Piranti kohesi gramatikal yang ditemukan sebanyak 22 data yang terdiri atas 10 referensi, 6 konjungsi, 3 substitusi, dan 3 elipsis. Piranti kohesi referensi dibagi menjadi 7 referensi persona, 2 referensi demonstratif, dan 1 referensi komparatif. Referensi persona dibagi menjadi 1 pronomina orang pertama tunggal, 1 pronomina orang pertama jamak, 4 pronomina orang ketiga tunggal, dan 1 pronomina orang ketiga jamak. Adapun piranti kohesi leksikal yang dianalisis dalam penelitian ini terdiri atas 7 ekuivalensi, 2 hiponimi, 2 antonimi, 2 repetisi, 1 sinonimi, dan 1 kolokasi.

Penelitian ini memiliki relevansi dengan penelitian Prasetia (2013) dengan judul "Penggunaan Piranti Kohesi dalam Karangan Narasi oleh Siswa Kelas VII SMP Negeri 1 Blahbatuh". Hasil penelitian ini menunjukkan bahwa piranti kohesi yang digunakan, antara lain piranti kohesi konjungsi 49\%, referensi 47,5\%, elipsis 1,8\%, repetisi 0,9\%, dan hiponimi 0,9\%. Adapun tingkat kekohesifan karangan narasi siswa kelas VII SMP Negeri 1 Blahbatuh tergolong rendah. Selanjutnya, relevansi penelitian ini dengan penelitian Prasetia yaitu samasama menganalisis teks naratif, terutama penggunaan piranti kohesi gramatikal dan leksikal. Temuan penelitian Prasetia yaitu piranti kohesi yang digunakan, antara lain piranti kohesi konjungsi, referensi, elipsis, repetisi, dan hiponimi. Adapun temuan pada penelitian ini yaitu piranti kohesi gramatikal yang dianalisis dalam penelitian ini terdiri atas referensi, konjungsi, substitusi, dan elipsis. Piranti kohesi leksikal yang dianalisis dalam penelitian ini terdiri atas ekuivalensi, hiponimi, antonimi, repetisi, sinonimi, dan kolokasi. Berikut ini akan ditunjukkan beberapa contoh hasil analisis data.

(1) "Kakak-kakak perempuan saya menangis tersedu-sedu di hari saya meninggalkan kampung halaman," imbuh Ronaldo. (Sumber: Beyond the Limit, Majalah Femina edisi 28 November-04 Desember 2015 halaman 76-77.)

Kalimat pada contoh (1) dianalisis dengan teknik daya pilah referensial dan baca markah. Contoh (1) mengandung penunjuk persona pertama tunggal, yakni saya. Penunjuk persona pertama tunggal tersebut mengacu secara kataforis pada konstituen di sebelah kanannya, yakni Ronaldo. Bentuk penunjuk persona pertama tunggal tidak hanya saya, tetapi ada juga $a k u$. Kedua pronomina pertama tunggal tersebut sebenarnya memiliki makna yang sama, tetapi penggunaannya berbeda. Bentuk saya digunakan untuk menyebut diri sendiri ketika berkomunikasi lisan dengan lawan bicara yang dianggap lebih dihormati, sedangkan aku digunakan untuk menyebut diri sendiri ketika berkomunikasi lisan dengan lawan bicara yang sebaya. 
Pada contoh (1) pronomina pertama tunggal dapat diganti dengan bentuk aku karena data tersebut merupakan bahasa tulis sehingga tidak akan menyimpang dari inti yang akan disampaikan. Jika pronomina saya sesudah frase di hari diganti dengan pronomina pertama tunggal aku maka pronomina saya sesudah frase kakak-kakak perempuan juga diubah. Akan tetapi, perubahan tersebut dalam bentuk pronomina empunya atau kepemilikan berupa enklitik $-k u$.

Adapun piranti kohesi leksikal yang dianalisis dalam penelitian ini terdiri atas ekuivalensi, hiponimi, antonimi, repetisi, sinonimi, dan kolokasi. Berikut ini akan ditunjukkan contoh hasil analisis data yang termasuk dalam piranti kohesi leksikal.

(2) Guncangan hidup membuatnya melarikan diri dari ingar-bingar dunia hiburan. Namun, pada akhirnya ini semualah yang membuat Ully Triani (30), bintang film terbaru Rudy Soedjarwo, Stay with Me, jadi lebih mensyukuri hidup. (Sumber: Wacana berjudul Titik Balik Ully Triani, Majalah Femina edisi 31 Oktober-06 November 2015 halaman 52-53.)

Contoh (2) dianalisis menggunakan teknik baca markah. Pada contoh (2) terdapat piranti kohesi konjungsi pertentangan, yakni namun. Pernyataan guncangan hidup membuatnya melarikan diri dari ingar-bingar dunia hiburan dipertentangkan dengan pada akhirnya ini semualah yang membuat Ully Triani jadi lebih mensyukuri hidup. Pendeknya, konjungsi namun pada contoh (2) mempertentangkan guncangan hidup dengan rasa syukur.

Bahan ajar yang digunakan dalam penelitian ini berupa bahan ajar cetak. Bahan ajar dapat diperoleh dari berbagai jenis sumber, salah satunya menggunakan wacana dalam rubrik "Selebritas" pada majalah Femina. Hasil analisis wacana dalam rubrik "Selebritas" pada majalah Femina dapat digunakan sebagai bahan ajar di Sekolah Menengah Pertama (SMP) kelas VII. Bahan ajar wacana dalam rubrik "Selebritas" pada majalah Femina disusun berdasarkan Kompetensi Inti dan Kompetensi Dasar pada Kurikulum 2013. Hasil penelitian ini digunakan sebagai bahan ajar di kelas VII Kompetensi Inti 4 dan Kompetensi Dasar 4.5.1. Berikut deskripsi Kompetensi Inti dan Kompetensi Dasar yang digunakan.

Mata Pelajaran : Bahasa Indonesia

Kelas : VII

Kompetensi Inti : 4. Mencoba, mengolah, dan menyaji dalam ranah konkret(menggunakan, mengurai, merangkai, memodifikasi, dan membuat) dan ranah abstrak (menulis, membaca, menghitung, menggambar, dan mengarang) sesuai dengan yang dipelajari di sekolah dan sumber lain yang sama dengan sudut pandang /teori.

Kompetensi Dasar : 4.5.1 Menyusun kejadian, urutan peristiwa, dan pesan ke dalam bentuk narasi tulis dengan memperhatikan penggunaan kosakata yang tepat dan kalimat yang efektif.

Indikator

1. Menggunakan bahasa Indonesia untuk sarana kegiatan belajar di lingkungan sekolah dalam bentuk lisan dan tulisan.

2. Menunjukkan perilaku jujur dan tanggung jawab dalam menanggapi teks cerita pendek.

3. Menguraikan struktur teks narasi dan kebahasaannya.

4. Menyusun teks narasi dengan memperhatikan penggunaan kosakata yang tepat dan kalimat yang efektif. 
Dari 37 data yang telah dianalisis hanya 23 data yang biasa diajarkan di sekolah sebagai bahan ajar menulis teks narasi. Piranti kohesi gramatikal yang biasanya diajarkan di sekolah, yaitu referensi dan konjungsi. Adapun piranti kohesi leksikal yang biasa diajarkan di sekolah, yaitu repetisi, antonimi, hiponimi, dan sinonimi. Berikut salah satu contoh data yang dapat digunakan sebagai bahan ajar menulis teks narasi yang berkaitan dengan penggunaan piranti kohesi.

(3) Waktu itu pula, di buku karya Luca Caioli, Ronaldo: The Obsession for Perfection, ia mengaku untuk pertama kalinya naik pesawat, untuk menjalani tes penerimaan masuk ke klub yang menjadi pujaan ibunya. Meskipun, kalau boleh memilih, Ronaldo sebetulnya ingin mendaftar ke Benfica, klub yang menjadi idola ayah dan saudara laki-lakinya. (Sumber: Beyond the Limit, Majalah Femina edisi 28 November-04 Desember 2015 halaman 76-77.)

Pada contoh (3) terdapat piranti kohesi konjungsi konsesif, yakni meskipun. Konjungsi tersebut digunakan untuk menyatakan keadaan dua pernyataan yang mengalami pertentangan. Pada contoh (3) terdapat pernyataan bahwa Ronaldo menjalani tes masuk ke klub idola ibunya yang bertentangan dengan keinginan Ronaldo yang sebenarnya lebih memilih untuk masuk ke klub idola ayah dan saudara laki-lakinya. Dengan demikian, konjungsi meskipun mempertentangkan antara keinginan dan kenyataan.

\section{SIMPULAN}

Berdasarkan analisis data mengenai penggunaan piranti kohesi gramatikal dan piranti kohesi leksikal yang terdapat dalam wacana rubrik "Selebritas" pada majalah Femina didapat simpulan sebagai berikut.

1. Piranti kohesi gramatikal yang dianalisis dalam penelitian ini terdiri atas referensi, konjungsi, substitusi, dan elipsis. Piranti kohesi referensi dibagi menjadi referensi persona, referensi demonstratif, dan referensi komparatif. Referensi persona dibagi menjadi pronomina orang pertama tunggal, pronomina orang pertama jamak, pronomina orang ketiga tunggal, dan pronomina orang ketiga jamak.

2. Piranti kohesi leksikal yang dianalisis dalam penelitian ini terdiri atas ekuivalensi, hiponimi, antonimi, repetisi, sinonimi, dan kolokasi.

3. Hasil penelitian ini digunakan sebagai bahan ajar di Sekolah Menengah Pertama (SMP) kelas VII sesuai dengan Kurikulum 2013. Bahan ajar ini dapat diterapkan pada Kompetensi Inti 4 dan Kompetensi Dasar 4.5.1 yakni siswa diminta untuk menyusun teks narasi.

\section{DAFTAR PUSTAKA}

Chaer, Abdul. 2012. Linguistik Umum. Jakarta: PT Rineka Cipta.

Chao, Chunhong. 2014. "Lexical Cohesion of Sino-British College Student's EAP Writing". Scholarly Journals. Volume 4 Number 10. Pages 2123-2128.

Ghufron, Syamsul. 2012. "Peranti Kohesi dalam Wacana Tulis Siswa: Perkembangan dan Kesalahannya". Jurnal Bahasa dan Seni. Volume 6 Nomor 2. Halaman 1-12.

Lestari, Ika. 2013. Pengembangan Bahan Ajar Berbasis Kompetensi. Padang: Akademia Permata.

Mulyana. 2005. Kajian Wacana: Teori, Metode \& Aplikasi Prinsip-Prinsip Analisis Wacana. Yogyakarta: Tiara Wacana. 
Nabifar, Nesa and Gholamreza Rostami. 2015. "A Constrative Study of Lexical Cohesion Used in Sport Texts in Washington and Tehran Times Newspapers Written by English Native and Iranian Authors". Modern Journal of Language Teaching Methods. Volume 5 Number 4. Pages 549-558.

Olajoke, Akinkurolere Susan. 2015. "A Lexical Analysis of an Inaugural Speech of the Speaker of Benue State House of Assembly in Nigeria". Journal of Language Teaching and Research. Volume 6 Nomor 2. Pages 258-264.

Parwati, Edin. 2011. "Kohesi Leksikal Repetisi pada Wacana "Wayang Durangpo" dalam Surat Kabar Harian Jawa Pos Edisi Februari-April 2010”. Jurnal Artikulasi. Volume 12 Nomor 2. Halaman 807-816.

Prasetia, I Made Prapta. 2013. "Penggunaan Piranti Kohesi dalam Karangan Narasi Oleh Siswa Kelas VII SMP Negeri 1 Blahbatuh”. Jurnal Jurusan Pendidikan Bahasa dan Sastra Indonesia. Volume 1 Nomor 8. Halaman 1-14.

Rani, Abdul, Bustanul Arifin, dan Martutik. 2006. Analisis Wacana: Sebuah Kajian Bahasa dalam Pemakaian. Malang: Bayumedia Publising.

Rassouli, Masoumeh dan Mehdi Abbasvandi. 2013. "The Effects of Explicit Instruction of Grammatical Cohesive Devices on Intermediate Iranian Learner's Writing". European Online Journal of Natural and Social Sciences. Volume 2 Number 2. Pages 15-22.

Rohmadi, Muhammad dan Yakub Nasucha. 2015. Dasar-Dasar Penelitian Bahasa, Sastra, dan Pengajaran. Surakarta: Pustaka Briliant.

Sudaryanto. 1993. Metode dan Aneka Teknik Analisis Bahasa. Yogyakarta: Duta Wacana University Press.

Tim Redaksi KBBI Pusat Bahasa. 2014. Kamus Besar Bahasa Indonesia. Jakarta: PT Gramedia Pustaka Umum. Edisi IV Cetakan Kedelapan.

Zarepour, Fatemeh. 2016. "Cohesion Analysis of Iranian Advanced EFL Learner's Writing". Journal of Language Teaching and Research. Volume 7 Number 2. Pages 408-414. 